\title{
PELATIHAN PENGEMBANGAN SOAL MATEMATIKA DAN IPA BERBASIS HIGHER ORDER THINGKING DALAM UPAYA MENINGKATKAN KOMPETENSI PEDAGOGIK GURU SD DI KECAMATAN GOLEWA BARAT
}

\author{
Yosefina Uge Lawe1), Dek Ngurah Laba Laksana²), Melkior Wewe ${ }^{3)}$, Natalia Rosalina \\ Rawa $^{4}$, Maria Yuliana Kua ${ }^{5}$ \\ 1,2,3,4,5)Program Studi PGSD, \\ 1,2,3,4,5)Sekolah Tinggi Keguruan dan IImu Pendidikan Citra Bakti) \\ ${ }^{1) y o s e f i n a g e l a w e @ g m a i l . c o m},{ }^{2}$ laba.laksana@citrabakti.ac.id, 3)melkiorwewe1@gmail.com, \\ ${ }^{4)}$ nataliarosalinarawa@gmail.com, ${ }^{5)}$ yulianakua03@gmail.com
}

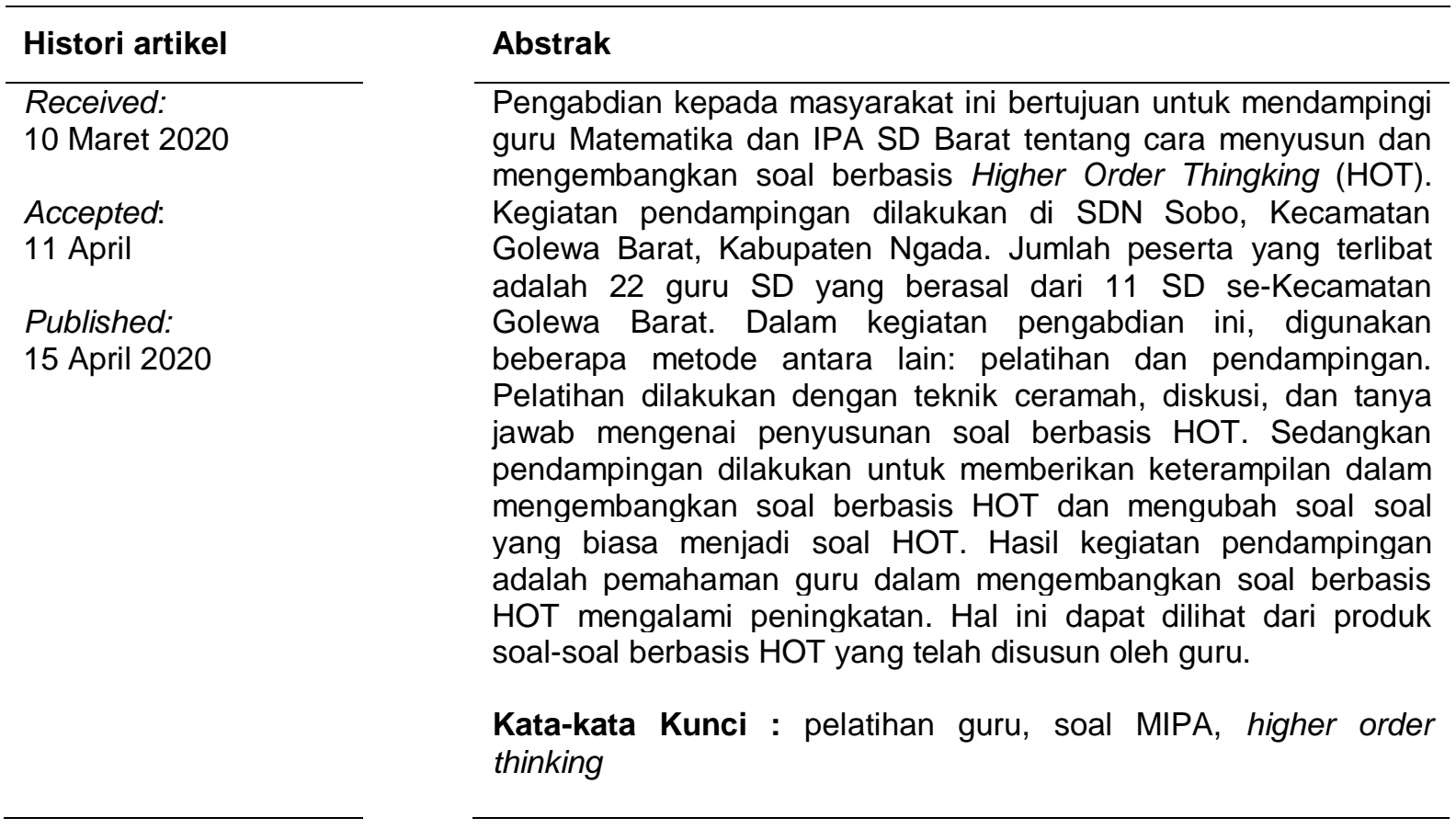


Abstract. This community service program aimed to assist elementary school mathematics and science teachers on how to arrange and develop questions originating from High Order (HOT). Assistance activities were carried out at Sobo Elementary School, Golewa Barat District, Ngada Regency. The number of participants involved was 22 elementary school teachers from 11 elementary schools in West Golewa District. In this service, several methods were used including: training and mentoring. The training was carried out with lecture, discussion, and question and answer techniques regarding the preparation of HOT questions. While the assistance was carried out to provide assistance in developing HOT questions and turning ordinary questions into HOT questions. The result of the mentoring activity is the teacher's understanding in developing HOT-based questions improve. This can be seen from HOT-based questions products that have been prepared by the teacher.

Keywords: teacher exercises, mathematic and science question, higher order thinking

\section{PENDAHULUAN}

Manusia memerlukan pendidikan sebagai bekal untuk menghadapi persaingan global yang semakin maju. Karena pendidikan merupakan wadah pembentukan kepribadian seseorang dan hakikatnya memanusiakan manusia yang berakal budi. Menurut Undangundang No. 20 Tahun 2003 tentang Sisdiknas dikatakan bahwa pendidikan adalah usaha sadar dan terencana untuk mewujudkan suasana belajar dan proses pembelajaran agar peserta didik secara aktif mengembangkan potensi dirinya untuk memiliki kekuatan spiritual, keagamaan, kepribadian, kecerdasan, akhlak mulia serta keterampilan yang diperlukan secara rasional dengan pengembangan diri demi mewujudkan potensi yang memadai dalam bidang pendidikan. Berdasarkan pengertian pendidikan tersebut, maka belajar adalah lebih dari sekedar mengingat atau mengafal. Bagi siswa untuk dapat sungguh-sungguh mengerti dan dapat menerapkan ilmu pengetahuan, mereka harus mencoba untuk memecahkan masalah dan berusaha menemukan sesuatu bagi dirinya sendiri (Lawe, 2017).

Sebagai seorang Guru yang mempunyai tugas utamanya adalah mendidik dan mengajar, maka sangat penting untuk mengetahui dan mengikuti kegiatan pelatihan Pengembangan Soal HOT (Higher Order Thinking) untuk mata pelajaran Matematika dan IPA sebagai Peningkatan Kompetensi Pedagogik Guru hasil dari pekerjaannya. Seorang guru harus mengetahui sejauhmana peserta didik telah menyerap dan menguasai materi yang telah diajarkan. Sebaliknya, peserta didik juga membutuhkan informasi tentang hasil pekerjaannya. Hal ini hanya dapat diketahui jika seorang guru melakukan evaluasi. Sebelum melakukan evaluasi, maka guru harus melakukan penilaian yang didahului dengan pengukuran (Wildan dkk, 2019).

Berdasarkan Undang-Undang Nomor 14 Tahun 2005 tentang Guru dan Dosen, kompetensi pedagogik merupakan kemampuan yang berkaitan dengan pemahaman peserta didik dan pengelola pembelajaran yang mendidik dan dialogis. Secara substansi, salah satu kompetensi ini berupa kemampuan guru dalam mengevaluasi hasil belajar peserta didik. Berdasarkan pendapat Marsh (dalam Salirawati, 2017) yang menyatakan bahwa salah satu kompetensi yang harus dimiliki guru adalah kemampuannya dalam melakukan penilaian, baik terhadap proses maupun produk pembelajaran. 
Laporan hasil Trends in International Mathematics and Science Study (TIMSS) pada tahun 2011 menyatakan bahwa rata-rata skor prestasi sains peserta didik Indonesia sebesar 406 (peringkat 40 dari 42 negara) (Salirawati, 2017). Demikian juga rata-rata skor prestasi matematika peserta didik Indonesia pada tahun yang sama sebesar 389 (peringkat 41 dari 45 negara) (Rosnawati, dalam Salirawati, 2017).

Banyak soal yang ditanyakan dalam TIMSS yang memang tidak terdapat dalam kurikulum Indonesia, menyebabkan guru harus berpikir ulang tentang kecukupan materi yang diberikan kepada peserta didik (asas adekuasi). Selain itu, peserta didik belum terbiasa memecahkan soal yang berkaitan dengan aplikasi konsep dalam kehidupan dan soal yang memerlukan penalaran (Fanani, 2018).

Hampir sebagian besar soal-soal sains dalam TIMSS yang mengungkap aspek aplikasi (applying) dan penalaran (reasoning) tidak dapat dijawab oleh sebagian besar peserta didik Indonesia. Soal-soal tersebut hanya dapat dijawab jika peserta didik terbiasa diajarkan untuk menggunakan logika dan penalarannya dan selalu mengaitkan materi pelajaran dengan aplikasinya dalam kehidupan (Widana, 2017).

Berdasarkan hasil TIMSS itulah, saat ini guru diharapkan mampu menyusun soal yang Higher Order Thinking (HOT), yaitu soal-soal yang mampu mengungkap kognitif tingkat tinggi. Namun, untuk menyusun soal HOT masih banyak guru yang belum memahami dan menguasainya, baik ciri-ciri soal HOT maupun bagaimana mengubah soal biasa menjadi soal HOT. Bahkan soal Uji Kompetensi Guru (UKG) yang baru-baru ini dilaksanakan mengarah pada soal yang termasuk dalam kategori soal HOT ((Widana, 2017).).

Guru mata pelajaran Matematika dan IPA SD penting untuk dilatih untuk menyusun dan mengembangkan soal yang mampu merangsang siswa untuk bisa berpikir tingkat tinggi, karena Hal tersebut sejalan dengan harapan yang tertera di dalam Peraturan Pemerintah (PP) Nomor 19/2005 Pasal 19 Ayat 1 yang menyatakan bahwa proses pembelajaran pada satuan pendidikan diselenggarakan secara inspiratif, interaktif, menyenangkan, menantang, dan memotivasi peserta didik untuk berpartisipasi aktif. Memberikan soal HOT keadaan siswa bertujuan untuk dapat menciptakan suasana belajar yang dapat merangsang siswa tertantang untuk berpikir dan menggunakan penalarannya.

Dalam melakukan proses evaluasi, khususnya pada aspek penilaian yang berkaitan dengan ranah kognitif, seorang guru dituntut untuk dapat mengembangkan berbagai instrumen penilaian yang memadai yang mampu mengungkap secara terstruktur kemampuan peserta didik. Selama ini, relatif belum pernah ada pengujian terhadap kualitas dan kelayakan soal yang disusun guru sehingga dari waktu ke waktu soal yang digunakan pada saat melakukan evaluasi atau ujian selalu sama (Laksana, 2014). Padahal perkembangan pola pikir anak didik semakin maju yang seharusnya diikuti dengan kemampuan guru dalam membuat soal yang dapat mengungkap aspek kognitif tingkat tinggi, 
seperti soal aplikasi (applying) dan soal penalaran (reasoning). Bentuk soal yang mampu mengungkap kognitif tingkat tersebut dikenal dengan istilah soal HOT yang seharusnya dikuasai oleh guru, agar anak didik terbiasa dengan soal yang menantang daya pikir dan penalarannya. Namun, pada kenyataannya masih banyak guru yang belum memahami dan menguasai cara penyusunan dan pengembangan soal HOT seperti yang dianjurkan dalam Kurikulum 2013 (Wildan dkk, 2019).

Kegiatan Pengabdian Pada Masyarakat (PPM) ini bertujuan untuk memberikan pemahaman tentang bagaimana cara menyusun dan mengembangkan soal-soal Matematika dan IPA yang dapat merangsang siswa untuk bisa berpikir tingkat tinggi, selain itu kegiatan ini juga diharapkan dapat memberikan pengalaman langsung bagi guru-giri Matematik dan IPA SD di kecamatan Golewa barat dalam mendesain soal biasa menjadi soal yang menuntut kemampuan tingkat tinggi (HOT) dan dalam pengembangan soal HOT bagi guruguru Matematika dan IPA SD se-Kecamatan Golewa Barat. Melalui kegiatan PPM ini diharapkan mampu menumbuhkan kesadaran guru-guru Matematika dan IPA se-Kecamatan Golewa Barat tentang pentingnya mengembangkan kemampuan mengevaluasi peserta didik dengan selalu mengikuti perkembangan yang terjadi di dunia pendidikan, sehingga dapat meningkatkan kompetensi pedagogiknya. Akhirnya, diharapkan peserta pelatihan PPM ini dapat menularkan pengetahuan yang diperoleh kepada Matematika dan IPA yang belum mendapat kesempatan mengikuti kegiatan ini, maupun guru mata pelajaran lainnya, baik di lingkungan sekolahnya masing-masing maupun sekolah lain dalam satu wilayah maupun di luar wilayah Kecamatan Golewa Barat.

\section{METODE PELAKSANAAN}

Kegiatan ini ditujukan bagi guru-guru Matematika dan IPA se-Kecamatan Golewa Barat sebanyak 22 orang guru Matematika dan IPA dari 11 SD yang ada di kecamatan Golewa Barat. Kegiatan pengabdian kepada masyarakat ini untuk bertujuan untuk memberikan pengetahuan bagi guru Matematika dan IPA SD dalam menyusun dan mengembangkan soal-soal yang dapat merangsang siswa untuk berpikir tingkat tinggi,selain itu juga kegiatan ini diharapkan dapat memberikan pengalaman langsung bagi guru Matematika dan IPA dalam mendesain soal-soal yang biasa menjadi soal yang dapat mengembangkan pengetahuan dan keterampilan berpikir tingkat tinggi siswa SD.

Kegiatan Pengabdian Pada Masyarakat ini sangat bermanfaat, terutama bagi guruguru Matematika dan IPA SD se-Kecamatan Golewa Barat adalah menyampaikan pengetahuan tentang bagaimana cara menyusun dan mengembangkan soal-soal yang dapat merangsang kemampuan berpikir tingkat tinggi siswa SD, baik yang dilakukan melalui praktik atau kerja langsung yang kemudian dilaporkan,sehingga para peserta mampu mengetahui kelemahanya dalam mengerjakan soal latihan tersebut. Selain itu, PPM ini 
diharapkan bermanfaat dalam menumbuhkan partisipasi pada guru-guru tentang keuntungan menyusun dan mengembangkan kemampuan mengevaluasi siswa dengan selalu mengikuti perkembangan yang terjadi di dunia pendidikan sehingga mampu meningkatkan kompetensi pedagogiknya. Guru Matematika dan IPA yang mendapat kesempatan mengikuti pelatihan nantinya diharapkan dapat menyebarluaskan materi PPM ini, baik kepada guru Matematika dan IPA lain maupun guru mata pelajaran lainnya, baik di lingkungan sekolah masingmasing maupun guru dari sekolah yang lain dalam satu wilayah maupun di luar Kecamatan Golewa Barat.

Pengabdian pada Masyarakat ini dilaksanakan pada Kamis - Sabtu pada tanggal 2022 Februari 2020 yang berlokasi Aula SDN Sobo. Adapun metode yang dipakai dalam kegiatan PPM ini antara lain: ceramah, diskusi, dan diskusi tentang permasalahan yang berkaitan pengembangan soal HOT; selain itu ada kegiatan guru di beri latihan untuk mendesain soal yang semula biasa menjadi soal-soal yang dapat merangsang kemampuan berpikir tingkat tinggi siswa dan melakukan tugas kelompok berupa pengembangan soal HOT; serta melaporkan hasil kerja kelompok masing-masing, baik kelompok Matematika maupun kelompok IPA. Melalui metode-metode tersebut diharapkan peserta kegiatan PPM benar-benar memahami dan menguasai pengembangan soal HOT secara baik dan benar sehingga ketika kembali ke sekolah mampu menularkan kepada guru-guru lainnya dapat berhasil dengan baik dan benar.

\section{HASIL DAN PEMBAHASAN}

\section{Hasil}

Pelaksanaan Pengabdian Pada Masyarakat ini dilaksanakan sebanyak tiga kali pertemuan, berturut-turut pada setiap hari Kamis tanggal 20 Februari 2020, Jumat 21 Februari 2020, dan Sabtu, 22 Februari 2020 di Aula SDN Sobo. PPM terlaksana dengan baik dan lancar. Pertemuan pertama berupa sosialisasi kegiatan yang hanya dilaksanakan selama setengah hari, mulai pukul 08.00-13.00. Pertemuan kedua dan ketiga dilaksanakan mulai pukul 08.00-16.00, dengan jumlah yang hadir untuk pertemuan 1, 2, dan 3 berturutturut sebanyak 22 orang peserta.

Setiap kegiatan pelatihan diawali dengan sambutan oleh Ketua Tim PPM, yaitu Yosefina Uge Lawe, dilanjutkan sambutan Koordinator Wilayah Kecamatan Golewa Barat Bapak Benediktus Lagho, dan terakhir sambutan Kepala SDN Sobo, tempat pelaksanaan kegiatan PPM sekaligus membuka acara pelatihan. Pada pertemuan pertama, kegiatan pelatihan diisi dengan sosialisasi kegiatan PPM, analisis kebutuhan (need assessment), pemaparan secara garis besar latar belakang, maksud dan tujuan PPM yang disampaikan 
oleh ketua Tim PPM, yaitu Yosefina Uge Lawe. Pemaparan secara garis besar latar belakang, maksud dan tujuan PPM yang bertujuan agar para peserta memperoleh gambaran awal gagasan diadakannya kegiatan PPM ini dan juga mengetahui maksud dan tujuannya, serta manfaatnya bagi pengembangan wawasan guru-guru Matematika dan IPA SD, khususnya tentang hal-hal yang berkaitan dengan trend penilaian pada saat ini yang sejalan dengan Kurikulum 2013.

Pada pertemuan kedua, setelah selesai sambutan, dilanjutkan dengan pemaparan materi demi materi dari seluruh anggota Tim pelaksana PPM. Melalui penyampaian semua materi tersebut secara berturut-turut, diharapkan peserta pelatihan memperoleh pengetahuan yang utuh, komprehensif, dan lengkap, mulai dari sistem penilaian Kurtilas dan permasalahannya di lapangan, sampai aspek-aspek yang harus diperhatikan ketika menyusun instrumen penilaian, cara mengembangkan soal berdasarkan taksonomi Bloom yang telah direvisi, dan puncak nya tentang cara mengembangkan soal HOT. Pada pertemuan kedua ini dilakukan penilaian sikap, yaitu keaktifan peserta dalam mengikuti kegiatan dan kerjasama dalam menyelesaikan tugas antar anggota kelompok. Selain itu, juga dilakukan penilaian terhadap penguasaan soal HOT melalui tugas mandiri. Peserta pelatiham diminta mengubah 5 butir soal biasa menjadi soal HOT. Penilaian dilakukan berdasarkan kriteria soal yang termasuk soal HOT.

Pada akhir pertemuan kedua, selain ada pembagian kelompok yaitu kelompok Matematika dan Kelompok IPA, Kelompok Matematika dibimbing oleh Melkior Wewe dan Natalia Rosalina Rawa dan kelompok IPA dibimbing oleh Yosefina Uge Lawe, Dek Ngurah Laba Laksana dan Maria Yuliana Kua. Pada pertemuan ketiga, setelah selesai sambutan, dilanjutkan dengan presentasi setiap kelompok sesuai dengan materi pokok yang diperoleh ketika dilakukan pembagian kelompok mata pelajaran. Setiap kelompok dibimbing masingmasing sampai menghasilkan soal-soal yang berbasis HOT. Pada akhir pertemuan ketiga dilakukan presentase hasil diskusi kelompok masing tentang soal HOT yang sudah disusun bersama.

Setiap satu kelompok selesai mempresentasikan hasil pekerjaannya, maka secara langsung dilakukan tanya jawab dan diskusi yang diikuti oleh seluruh peserta pelatihan. Meskipun jumlah yang hadir hanya 22, diskusi tetap dapat berlangsung dengan seru dan hidup karena guru yang hadir sangat bersemangat memberi masukan dan mencari kebenaran tentang bentuk soal HOT. Oleh karena itu, agar pemahaman peserta sama, setiap akhir presentasi Tim Pelaksana PPM memberikan pemantapan konsep dan penjelasan bagaimana soal HOT yang benar untuk setiap butir soal yang dikembangkan oleh peserta pelatihan. Ada beberapa soal yang memang sudah benar, tetapi ada juga yang harus direvisi ringan atau berat (diganti). Pada umumnya, guru masih terjebak dengan soal 
bentuk lama karena sebagian dari mereka masih mengandalkan mengambil dari buku, bukan pengembangan soal dari pemikiran sendiri.

Sebelum kegiatan ditutup, peserta diberi lembar evaluasi pelaksanaan kegiatan PPM sebagai refleksi terhadap kebermanfaatan kegiatan pelatihan ini bagi peserta dan juga untuk menjaring saran-saran dan harapan peserta terhadap kegiatan ini.

\section{Pembahasan}

Pengabdian Pada Masyarakat dapat dilaksanakan dengan baik dan tanpa hambatan berkat dukungan semua pihak, baik dari Koordinator Wilayah Kecamatan Golewa Barat guru-guru Matematika dan IPA SD Se-Kecamatan Golewa Barat sebagai peserta PPM yang sangat bersemangat dalam mengikuti kegiatan PPM dari awal kegiatan sampai selesai, maupun seluruh pihak yang terlibat dalam kegiatan ini, termasuk Tim PPM dan mahasiswa yang dilibatkan dalam PPM dengan antusias tinggi dalam melaksanakan kegiatan PPM dengan sebaik-baiknya. Antusias seluruh peserta pelatihan membuat kegiatan ini terlihat semarak dan meriah. Hal ini ditunjukkan dengan kehadiran peserta pelatihan sesuai dengan undangan, bahkan beberapa di antaranya hadir sebelum pukul 08.00.

Pengabdian pada Masyarakat dapat dilaksanakan dengan baik karena berkat dukungan dana dari DIPA Yapentri Tahun Anggaran 2020 yang turun tepat pada waktunya dan cukup memadai sehingga dapat memberikan motivasi bagi Tim Pelaksana untuk melaksanakan kegiatan PPM dengan sebaik-baiknya. pelatihan ini harus dilaksanakan karena bagi guru-guru Matematika dan IPA SD di Kecamatan Golewa Barat merupakan materi dan pengetahuan baru bagi mereka yang harus mereka laksanakan guna mendukung kemampuan pedagogik dan sesuai dengan perkembangan ilmu pengetahuan sesuai dengan perubahan pada dunia pendidikan saat ini. Selain itu, dari hasil observasi di lapangan dan informasi dari guru-guru Matematika dan IPA SD se-Kecamatan Golewa Barat melalui angket penilaian yang diberikan pada saat sosialisasi awal kegiatan dan pada pertemuan pemantapan, sebagian besar menyatakan belum pernah diadakan pelatihan dengan topik soal HOT bagi guru-guru Matematika dan IPA SD. Kedua alasan itulah yang membuat Tim PPM semakin yakin bahwa topik PPM yang akan dilatihkan sangat dibutuhkan di lapangan.

Faktor penghambat dalam pelaksanaan kegiatan pelatihan ini hampir tidak dijumpai, karena jalinan kerjasama antara Tim Pelaksana PPM dengan Koordinator Wilayah Kecamatan Golewa Barat dan seluruh pengurusnya relatif baik sejak koordinasi sampai berlangsungnya kegiatan pelatihan, baik saat pertemuan pertama, kedua, maupun ketiga. Begitu juga halnya dengan jumlah peserta yang hadir.

kegiatan pelatihan ini berhasil dilaksanakan dan tepat sasaran yaitu bagi guru Matematika dan IPA SD, karena sebagian besar peserta menyatakan bahwa pelatihan ini memberikan banyak manfaat khususnya mengetahui seluk-beluk soal HOT serta 
pengembangannya. Harapannya, peserta benar-benar dapat terus mengembangkan soalsoal serupa, jika perlu mengajak guru-guru lainnya, sehingga menjadi luas kemanfaatannya. Kegiatan ini hanyalah salah satu bentuk kepedulian Tim Pelaksana PPM STKIP Citra Bakti dalam ikut andil membantu meningkatkan mutu pendidikan Indonesia agar dapat bersaing di kancah Internasional.

\section{KESIMPULAN}

Pengabdian kepada masyarakatat (PPM) bertujuan untuk mendampingi guru Matematika dan IPA SD di Kecamatan Golewa Barat tentang bagaimana cara menyusun dan mengembangkan soal Higher Order Thingking (HOT) yang bermutu dan berkualitas, serta memberikan pengalaman langsung dalam mengubah soal yang biasa menjadi soal yang membantu merangsang siswa untuk bisa berpikir tingkat tinggi. Tujuan lain juga adalah agar memacu guru Matematika dan IPA SD di Kecamatan Golewa Barat untuk mengetahui tentang pentingnya melakukan penyusunan soal-soal yang berkualitas baik sebagai bentuk cara mengevaluasi sejauh mana guru-guru sudah mampu mengikuti perkembangan yang terjadi pada dunia pendidikan, hal ini juga menunjang kemampuan padgogik dari guru tersebut. Dalam kegiatan PPM ini, digunakan beberapa Metode antara lain: ceramah, diskusi, dan tanya jawab tentang masalah-masalah yang dihadapi guru dalam menyusun soal-soal berbasis HOT, selain itu metode lain yang digunakan untuk menunjang pelaksanaan kegiatan ini adalah latihan oleh masing-masing guru Matematika dan IPA dalam mengubah soal yang biasa menjadi soal HOT dan melakukan diksusi kelompok berupa penyusunan dan pengembangan soal HOT; serta melaporkan hasil diksusinya. Pelaksanaan Kegiatan PPM ini berhasil dilakukan karena langsung memberikan ppengetahuan kepada guru Matematika dan IPA SD mengenai ciri khas dan cara penyusunan soal HOT yang berkualitas baik.

\section{DAFTAR PUSTAKA}

Depdiknas. (2005). Peraturan Pemerintah Republik Indonesia Nomor 19 Tahun 2005 tentang Standar Nasional Pendidikan. Jakarta: Depdiknas

Depdiknas. (2005). Undang-undang Republik Indonesia Nomor 14 Tahun 2005 tentang Guru dan Dosen. Jakarta: Depdiknas.

Salirawati, D. (2017). Pelatihan pengembangan soal HOT. Jurnal Pengabdian, 21(1)

Lawe, Y.U. (2017). Penerapan model pembelajaran contextual teaching and learning (CTL) untuk meningkatkan aktivitas dan hasil belajar IPA pada siswa kelas IV SDI Olaewa kecamatan Boawae kabupaten Nagekeo. Jurnal Pendidikan IImiah, 4(1)

Fanani, M.Z. (2018). Strategi pengembangan soal higher order thinking skill (HOTS) dalam kurikulum 2013. Journal of Islamic Religious Education, 2(1), 57-76

Laksana, D.N.L. (2014). Profil pemahaman konsep IPA guru-guru kelas sekolah dasar di Kabupaten Ngada. Jurnal IImiah Pendidikan Citra Bakti, 1(1), 15-26 
Widana, I.W. (2017). Modul: penyusunan soal higher order thinking skill (HOTS). Jakarta: Direktorat Jenderal Pendidikan Dasar dan Menengah, Kemendikbud

Wildan., Hakim, A., Laksmiwati, D., Savalas, L.R.T., \& Supriadi. (2019). Sosialisasi dan pendampingan pengembangan instrumen hasil belajar berbasis keterampilan berpikir tingkat tinggi (HOTS) pada mahasiswa magister pendidikan IPA Universitas Mataram. Jurnal Pengabdian Magister Pendidikan IPA, 2(1), 28-33 